\title{
Describing the Students' Grammatical Errors on Spoken English
}

\author{
Imanuel Kamlasi \\ English Lecturer of English Education Study Program of Timor University \\ Jl. Km. 9, Kelurahan Sasi, Kefamenanu, Timor, NTT, Indonesia \\ E-mail address: ikamlasi@yahoo.com Hp. 085239295604
}

\begin{abstract}
This present study describes the students' grammatical errors on spoken English based on the classifications of errors refer to Dulay, Burt and Krashen's theories. Qualitative method was used in the study. Oral test was used as the research instrument. There were 25 participants of English education study program of Timor University who were chosen randomly as the research sample. The Tape Video Recording (TVR) was used to gain data of spoken English. There were five techniques in analyzing the data: transcription, codification, classification, analyses and discussion. The results of data analyses revealed that omission presented $40,87 \%$ of errors. Then; addition presented $31,74 \%$ and misformation presented $15 \%$. The misorderning was categorized as the lowest score with $12,30 \%$. In linguistic category; the data showed that verb was categorized as the highest errors which presented $19 \%$ of errors. The next error was preposition which presented $17 \%$. Then pronouns category presented $14 \%$ of errors. The conjunction and article categories presented $11 \%$ of errors on spoken English. The singular/plural and negation categories presented $10 \%$ of errors for each category. The lowest error of linguistic category was word order which presented $8 \%$ errors. The findings showed that the students still make errors on linguistic category on spoken English. There was a phenomenon in this finding that the students tend to use verb-ing instead of using verb-1 in the spoken English. They dispose to add and omit any linguistic category unconsciously when they speak.
\end{abstract}

Keywords: errors, grammar, spoken 


\section{INTRODUCTION}

Speaking for Everyday Communication is one of the subjects which is taught for the first year students of English education study program of Timor University. The purpose of this subject is to help the students to perform their speaking ability regarding to the everyday communication. Therefore; the topics in this subject refer to the daily communication. One of the topics is Telling Daily Routines. In this topic students prepare their daily activities and tell it orally to other students in front of the class. During my experiences in teaching speaking for a couple of years; many of the students still have problems in oral presentation. On other hand; they have difficulties to speak. Some students just keep silent or event say some words or sentences during the presentation or conversation practice. My impression to this case that; speaking subject is classified as one of the difficult subjects for the first year students of English Education study program. The students still have problems in pronouncing correct English pronunciation, choosing appropriate vocabularies, and in using good grammar of English.

The most common problem that the students make in speaking activities is how to use good English grammar. This problem never ends. My assumption is that English is different from Indonesia language or other local languages in the world. These languages are completely different in the system of sounds, words and sentences. In fact, language learners need a long time to learn a new language; because she/he must learn a new structure, thousands of new vocabularies and different pronunciation. In reality, learning a language is very different from our mother language. It also takes much practice to develop listening skill, speaking skill, reading skill and writing skills including the sub-skills; pronunciation, vocabulary and grammar. Therefore; making errors and mistakes are part of language learning.

In speaking process; speaker(s) need to consider the grammar or the rules of the language system. Thus, Batko, Ann \& Rosenheim (2004 p. 24) define grammar as the basic principles and structures of the language that include correct sentences and proper words forms. The use of good grammar produces meaning in communication. Grammar is used to make meaning for communication in oral or written communication. To use a language properly, it is important to know grammar of language and their meanings. Therefore grammar is important in speaking. In fact; many students still make errors in grammar. Students often make incorrect utterances in spoken English. Dulay (1982 p. 138) highlight errors are fault of learning in speaking performance. Spoken error is a part of conversation that depart from selected norm of mature language performance. 
However, making error is basic process for human thus; it is possible for language learners to make errors unconsciously in speaking process. Harmer (1983 p. 35) says that errors are the results of incorrect rule; language has been kept in the human brain incorrectly. Errors could happen in the classroom teaching and learning process. Errors maybe caused by teachers since they have the lack of grammar competences in English teaching. Errors are also caused by students since they have different understanding on grammar.

I found out so many grammatical errors in spoken English during classroom speaking activities. For example; I usually getting up at 5.00 o'clock in morning, then I tidied my bed room. After that, I taking and going to campus. The first and the third underline the student should change the tense to be present. The reason is the time signal of daily activity should use present. And the second underline, the student omits article the before morning, the student should put article the before morning.

This present study classifies and describes the students' grammatical errors in spoken English of the first semester students of English study program of Timor University in the academic year 2018/2019. The classifications of errors refer to Dulay, et al. (1982 pp. 154-163) which covers omission, addition, misformation and misordering. Even this study was conducted in a small participants but it is hoped to be useful for any lecturers and students to find out possible solutions to improve the grammar usage in spoken English.

\section{Review of Related Literature}

Dulay, et al., (1982 p. 139) define errors as flawed side of learners' speech or writing form. They stress that errors in oral and written depart from some selected norm in language performance. This means that error is a part of language learning. Language learners cannot avoid errors because errors mostly and naturally occur in learning process. Meanwhile; Brown (2000 p. 170) states that errors as a noticeable deviation from the adult grammar of a native speaker, reflecting the interlanguage competence of the learner. Every learner has different competence of level in learning English and it conduct that they have different type of error.

It is important to use correct grammar in oral communication; because the language will have meaning if the speakers tend to use good language grammar. Celce-Murcia (1995 p. 249) underlines the term grammar is essentially about the systems and patterns which is used to select and combine words. In studying grammar; language learners will identify the system which is as the language foundation. Krishnasamy (2015) says that grammar is regarded as the most fundamental element of language learning for second language learners. Realizing the important of grammar; it is taught in English language class. In fact; grammar is learnt by all language learners in all 
levels, elementary school up to university level.

A study on grammatical errors in spoken English conducted by Ting, et al. (2010) showed that the students developed grammatical accuracy towards the end of the oral communication class. In grammatical categories, the students produced fewer errors in the third role play compared to the first role play. The surface structure showed that misformation and omission made $72 \%$ of grammatical errors, while the addition and misordering were being less frequent. The linguistic description showed that preposition and question were the most difficult for the less proficient students which made $35 \%$ of total errors, and then it was followed by word form and article which made $11 \%$ for each. The other types of errors are relatively less frequent that cover subject-verb agreement, tense, plural form, pronoun, misordering of question and negative.

Furthermore; a study of grammatical errors on paragraph writing conducted by Ma'mu (2016) found 35 errors from the students' writing. He used Dulay, Burt, and Krashen's theories to describe the types of error that cover omission, addition, misformation, and misordering. The results revealed that most of them made errors in omission and another was misformation. The most common errors which were made by students were misformation with the number of errors was $43 \%$, omission with the number of error was $31 \%$.

\section{METHOD}

This investigation was conducted to classify and describe the grammatical errors in spoken English of the first year students of English study program of Timor University in the academic year 2018/2019. The classification of errors refer to theory of Dulay, Burt and Krashen (1982 pp. 154-163) in which covers omission, addition, misformation and misordering. Thus; the descriptive qualitative method was applied in the study. Creswell (2014 p. 234) mentioned the sources of data in qualitative research are in multiple forms, i.e. observations, documents, interviews, and audiovisual information rather than rely on a single source of data. The instrument of this study was speaking test. The students were given the clues to prepare their daily activities. There were two parallel classes in the first year students of English education study program of Timor University in academic year of 2018/2020 with the total numbers are 76 students. The participants of the study were 25 students chosen randomly as the sample of this research. The Tape Video Recording (TVR) was used to gain data of oral presentation. The participants were asked to tell their daily activities in oral presentation. The students' spoken English was recorded during their performance. There were five techniques used in analyzing the data namely transcription, codification, classification, analyses and discussion. In transcribing technique, the researcher listened carefully to the recording of spoken English and he 
transcribed the spoken form into written form. In codifying technique, the words, phrases, clauses or sentences which were used by students in oral presentation were given code. The codes were based on the classification of errors and linguistic category that refer to Dulay, Burt and Krashen (1982 pp. 154-163). In classifying techniques, the researcher classified the data into linguistic surface category. In analyzing technique, the researcher analyzed the data based on classification of errors and linguistic surface category. In discussion section, the researcher discussed the result descriptively as the findings of the research.

\section{FINDINGS AND DISCUSSION}

In this section, the findings of grammatical errors in spoken English are presented and discussed. The grammatical errors refer to Dulay, Burt and Kresen theory which covers omission, addition, misformation and misordering and linguistic category.

Chart 1. Types of Errors on Spoken

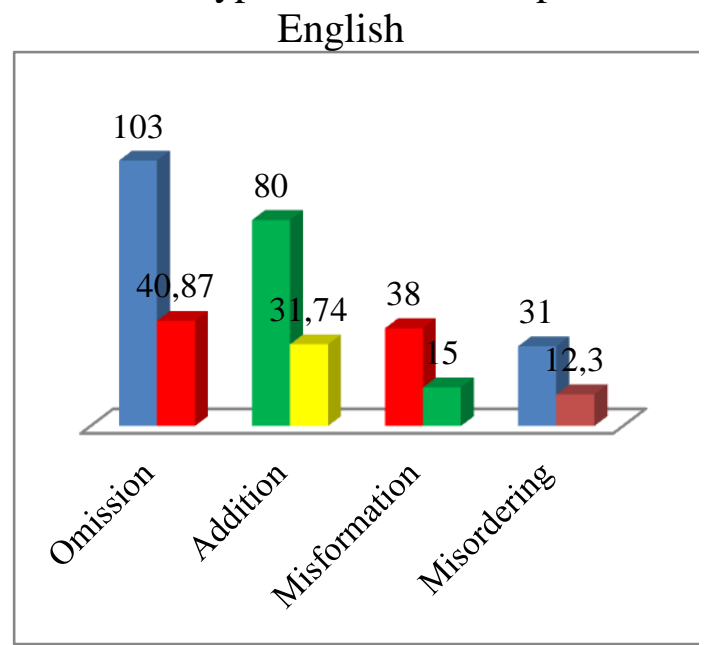

The results of the analysis of the classification errors shown in chart 1 showed that the highest grammatical errors on spoken English was omission within the total errors were 103 or $40,87 \%$. For example of omission errors in student number 1: I usually get up_5 o'clock. The student omits the preposition at before the time. There was an absence of article in the utterance. In English; preposition at is used before the hour. This is maybe caused by the interference of the Indonesian language; saya biasanya bangung jam lima pagi. The next error was followed by addition errors within the score 80 or $31,74 \%$. For example of addition errors in student number 1 : Then, I prepare to making by bed. This student produces addition errors of ing form. In English, the use of inventive to + verb 1; but normally many new learners use verb-ing instead of to infinitive. Student number 2: I go to home. There was an addition errors of to which is used before home. The correct is I go home (without preposition to). The next error was misformation within the total error were 38 or $15 \%$. For example in student number 15: I go to campus by foot. The student makes errors in using preposition by. In English; by is sued for car or motorcycle while the correct English grammar is I go to campus on foot. Student number 19: I usually have porridge and tea for $\boldsymbol{m e}$ breakfast. This error is categorized as misformation which the student uses me (object) instead of my as the possession before the noun. The last type error was misorderning which was categorized as 
the lowest score within 31 or $12,30 \%$. Example of misordering error in student number 18: I and my brother have dinner. In English; My brother and I have dinner. The students did not make many errors in misordering.

Chart 2. Interval Range in Types of Errors

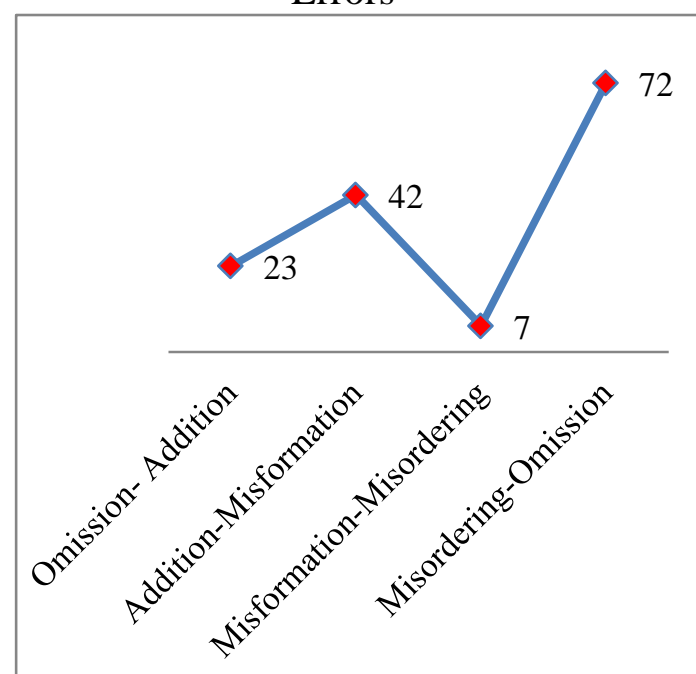

This chart presents the interval range in types of errors. The data showed that there was significant interval between the types of errors. The interval range in omission and addition was 23. The interval range in addition and misformation is 42 . The interval range in addition and misordering is 7 and the interval range in misordering and omission is 72 .
Table 1. Total of Errors on Linguistic Category

\begin{tabular}{|c|c|c|c|c|c|}
\hline 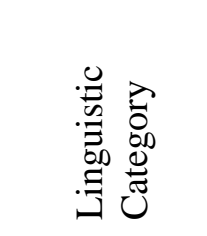 & 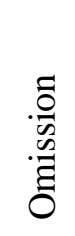 & $\frac{\tilde{0}}{: \frac{0}{0}}$ & 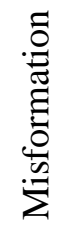 & 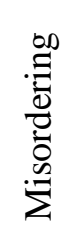 & $\sum$ \\
\hline Verb & 23 & 18 & 2 & 5 & 48 \\
\hline Pronoun & 18 & 10 & 8 & 0 & 36 \\
\hline Preposition & 21 & 14 & 5 & 2 & 42 \\
\hline Article & 15 & 8 & 6 & 0 & 29 \\
\hline $\begin{array}{l}\text { Singular/ } \\
\text { Plural }\end{array}$ & 9 & 11 & 4 & 0 & 24 \\
\hline Conjunction & 12 & 7 & 6 & 4 & 29 \\
\hline Word Order & 0 & 0 & 0 & 20 & 20 \\
\hline Negation & 5 & 12 & 7 & 0 & 24 \\
\hline Total & 103 & 80 & 38 & 31 & 252 \\
\hline
\end{tabular}

This table shows the total of errors made by first year students in the spoken English, based on linguistic category. The analyses focused on the present simple which refers the topic of speaking test. The error analysis showed the highest number of errors is verb within 48 errors. Student number 18: I studying at 8.00 o'clock. He used verb-ing instead of verb-1 in present simple. Student number 11: My campus start_at 8.00 o'clock. This error is categorized as omission in third singular subject, where the student omits $s$ in verb-1. The correct is my campus starts at 8.00 o'clock. The next error of linguistic category is preposition within 42 errors. Student number 12: My campus starts at 8.00 o'clock and finishes _ 1.00 o'clock. She omits the preposition at which should be used before the hour. Student 
number 24: I go to campus by public transportation but sometimes with motorcycle. My campus start at 8.00 o'clock, aa.. on campus my classmate and I tell a lot. This student uses with my friend motorcycle as dengan sepeda motor instead of by. The next, he makes error in using on campus. The correct is at campus. The pronoun category made 36 errors in spoken English. Examples as in student number 18: I take bath and_dresses at. This student omits subject $I$ which is put before the verb. Student number 5: I want to tell__ my daily activities. This student also omits object you which is put after the verb tell. While student number 19: I usually have porridge and tea for $\boldsymbol{m e}$ breakfast. This error is categorized as misformation which the student uses me (object) instead of $\boldsymbol{m y}$ as the possession which is used before the noun. Then, it is followed by article and conjunction which make 29 errors for each category. The error in article was made by student number 6 . I wash $\boldsymbol{a}$ dishes. There was error by adding article $\boldsymbol{a}$. The correct is I wash dishes. The error in conjunction made by the student number 5: I go to campus by motorcycle and my campus starts at 8.00 o'clock and at 2.00 o'clock. There was ungrammatical conjunction and. The conjunction and is used to connect two similar word class; i.e. noun + noun. The next errors of linguistic category are singular/plural and negation which make 24 errors for each category. Student number 14: I want to tell you about my daily activity. This student does not differentiate the singular and plural forms. The case in daily activity should be in plural form so it should be my daily activities. The example of negation is made by student number 12: Before I go to bed I no forget to pray. This student omits the auxiliary do which is use in negative form. The correct is I do not forget to pray. Student number 24: Some of us telling the story, aaa... to not get boring. This student means to inform that to avoid getting bored; they must tell the story. The correct is the story doesn't make boring. The last error of linguistic category is word order. The error of word order was made the student number 25. Usually I get up at 5.00 o'clock in the morning. There is error in word order in which the student put usually before the subject. The correct I usually get up at 5.00 o'clock. So, usually is put after subject.

Chart 3. Percentage of Errors based on Linguistic Category

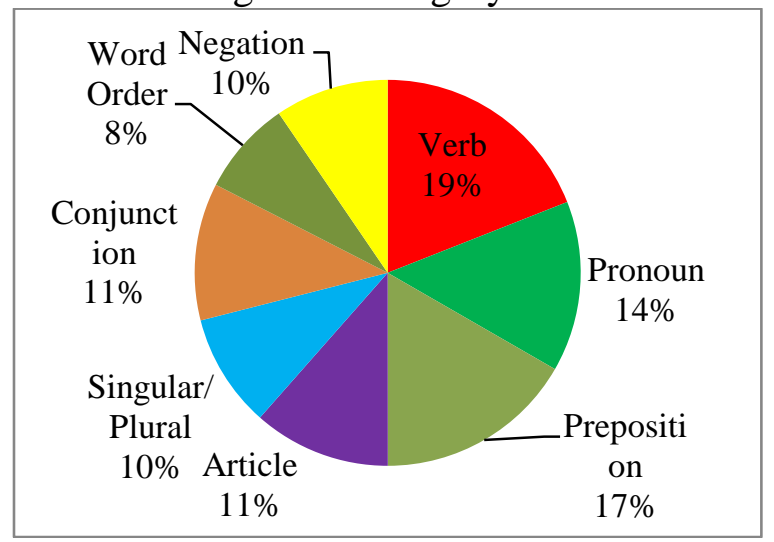

This chart presents the percentage of errors based on linguistic category on spoken English. The score showed that verb was categorized as the highest errors that the students make on spoken English. The verbs presented $19 \%$ of errors. The next error of linguistic category on spoken English was 
preposition. The preposition presented $17 \%$ of errors which was lower than verb. Then pronouns category presented $14 \%$ of errors which was higher than conjunction and article. Thus, the conjunction and article categories presented $11 \%$ of errors on spoken English. The singular/plural and negation presented $10 \%$ of errors for each category on spoken English. The score showed the slightly difference with conjunction and article. The lowest error of linguistic category was word order which presented $8 \%$ errors on spoken English. This finding showed that the students still make errors on linguistic category on spoken English.

\section{CONCLUSION}

After working on analyses during a couple of weeks, I have come to my conclusion of the study. Based on Dulay, Burt and Krashen's theory which I used to analyze the students' grammatical errors on spoken English; I found that the highest grammatical errors on spoken English was omission which presented 103 or $40,87 \%$ errors. Then; the addition presented 80 or $31,74 \%$ errors. While, the misformation presented 38 or $15 \%$. The misorderning error categorized as the lowest score with 31 or $12,30 \%$ of errors. The errors on linguistic category on spoken English showed that verb was categorized as the highest errors which presented 48 or $19 \%$ of errors. The next error of linguistic category on spoken English was preposition which presented 41 or $17 \%$ of errors. Then pronouns category presented 36 or $14 \%$ of errors. The conjunction and article categories presented 29 or $11 \%$ of errors on spoken English. The singular/plural and negation presented 24 or $10 \%$ of errors for each category on spoken English. The lowest error of linguistic category was word order which presented 20 or $8 \%$ of errors on spoken English. This finding showed that the students still make errors on linguistic category on spoken English. There was a phenomenon in this finding that the students tend to use verb-ing instead of using verb-1 in the spoken English. They dispose to add and omit any linguistic category unconsciously when they speak.

\section{REFERENCES}

Batko, Ann \& Rosenheim.(2004). When Bad Grammar Happens to Good People; How to Avoid Common Errors in English. USA: Career Press.

Brown, Douglas H. (2000). Principle of Language and Teaching, addision Wesley: Longman.

Celce-Murcia, M, (ed). (1995). Teaching English as a Second or Foreign Language, Third Edition. Rowley, MA: Newbury House.

Creswell, W. J. (2014). Research Design: Qualitative, Quantitative, and Mixed Methods Approaches.Fourth Edition. London: Sage Paublication Inc.

Dulay, H. Burt, M. Krashen, S. (1982). Language Two.Oxford University Press. New York 
Harmer, Jeremy. (1983). The practice of English Language Teaching. Longman. USA

Hie Ting, Su-Hie. Mahadhir, Mahanita. Chang, Siew-Lee. (2010). Grammatical Errors in Spoken English of University Students In Oral Communication Course.GEMA. Online ${ }^{\mathrm{TM}}$ Journal of Language Studies 53 Volume 10 (1) 2010 ISSN: 16758021

Krishnasamy, Jothimalar. (2015). Grammatical Error Analysis in Writing of ESL Diploma Students.Asian Journal of Education and e-Learning (ISSN: 2321 - 2454) Volume 03 - Issue 01, February 2015 Asian Online Journals (www.ajouronline.com)

Ma'mun, Nadiah. (2016). The

Grammatical Errors on the Paragraph Writings. Jurnal Vision, Volume 5 Number 1, April 2016 